\title{
Incremental Change in Housing Regimes: Some Theoretical Propositions with Empirical Illustrations
}

\author{
Bo Bengtsson
}

Institute for Housing and Urban Research, Uppsala University, Sweden

bo.bengtsson@ibf.uu.se

\section{Sebastian Kohl (corresponding author)}

Max-Planck Institute for the Study of Societies, Köln, Germany kohl@mpifg.de

\begin{abstract}
The durable structures of housing and housing institutions are often subject to long-term processes of incremental change. Nevertheless, housing studies have largely focused either on static snapshots of policies or, more recently, on the inertia of institutional path dependence, while processes of incremental change have been almost entirely neglected. Political scientists (Streeck/Thelen/Mahoney) have proposed a typology of patterns of incremental institutional change, and this paper explores the applicability of this typology to housing structures and housing institutions. We draw on empirical illustrations from the housing literature to show how five types of change - layering, conversion, displacement, drift, exhaustion - apply to housing structures and institutions. We conclude with some general observations on how the typology can be used in further studies of developments in national housing regimes.
\end{abstract}

Keywords: housing; institutional change; path dependence; housing structures; housing institutions.

MPIfG Journal Article

Bo Bengtsson, Sebastian Kohl: Incremental Change in Housing Regimes: Some Theoretical Propositions with Empirical Illustrations. In: Critical Housing Analysis 7(1), 15-24 (2020). Institute of Sociology, Academy of Sciences of the Czech Republic

The original publication is available at the publisher's web site: https://doi.org/10.13060/23362839.2020.7.1.500

The MPIfG Journal Articles series features articles by MPIfG researchers and visiting scholars published in peer-reviewed journals. Max Planck Institute for the Study of Societies (MPIfG) Cologne | www.mpifg.de 


\section{Housing and long-term change}

Housing as a good is highly durable, and housing policies and practices are also typically difficult to change. It takes generations for new construction to overhaul the existing stock, housing implies long-term investments, and mortgage loan amortisation can stretch over several decades. Governments usually inherit subsidy programmes and obligations from their predecessors. City systems are very stable, and city districts can keep their identity and defining characteristics over centuries. In the end, individuals pass on their housing wealth, and even housing preferences, to the next generation. Although these durable features of housing do seem to support a perspective that emphasises continuity and reinforcing mechanisms, only recently have housing studies made use of path-dependence approaches (Bengtsson and Ruonavaara 2010; Malpass 2011). However, a path-dependence perspective ignores phenomena of long-term incremental change. The cumulative effects of such changes contradict the default expectation of path-dependence approaches, which model change only through exogenous shocks that produce 'critical junctures'.

This paper employs the long-term perspective offered in path-dependence research on housing regimes. However, in order to understand patterns of incremental change, we explore the applicability of a typology developed in general welfare state research to the case of housing, more precisely Streeck and Thelen's typology of institutional change that has been further developed by Mahoney and Thelen, which from here on we will refer to as the 'STM model' (Mahoney and Thelen 2009; Streeck and Thelen 2005). In previous research, this model has been applied to welfare domains such as pensions, health, or education, but only rarely to housing phenomena. ${ }^{1}$

Housing regimes are special in that they are made up not only of institutions but also of large material infrastructures. For this reason, we first apply the STM typology to change in physical housing structures and then to the development of housing institutions, drawing on illustrative examples from the housing literature. We conclude by discussing how the typology can be applied in further studies of national housing regimes.

\section{Path dependence and housing - a general perspective}

A standard approach when studying long-term phenomena in housing is path dependence. The typical example of path dependence in politics is where institutions are designed at point $\mathrm{A}$, a critical juncture, and later, at point $\mathrm{B}$, these same institutions constrain decision-making, and thus make some policy alternatives impossible or implausible. Bengtsson and Ruonavaara (2010) identify the reinforcing mechanisms of path dependence as efficiency, legitimacy and power, implying that events at point A make some alternatives appear more efficient, more legitimate, or more powerful at point B. Mahoney has suggested that path dependence should be defined rather strictly as 'historical sequences in which contingent events set into motion institutional patterns or event chains that have deterministic properties' (Mahoney 2000: 507548). Unfortunately, a definition this strict would make incremental change virtually impossible. In this paper, where our interest is in gradual change, we employ a weaker, more open-ended definition of path dependence as a historical pattern where a certain outcome can be traced back to a particular set of events on the basis of empirical observation and guided by

\footnotetext{
${ }^{1}$ Notable exceptions are (Malpass 2011; Nielsen 2010; Sorensen 2015).
} 
some social theory (Bengtsson and Ruonavaara 2010; Crouch and Farrell 2004). This weak definition directs the focus on analysing how 'history matters' and which mechanisms keep the development on a certain path.

So far, the majority of path dependence-oriented studies on housing have focused on formal institutions, although there is also some work on path dependencies in building stock, quality, and regional housing distribution (Kohl 2016) and in social-stratification orders (Kährik 2006). In this paper, we discuss the STM model of gradual change in relation to housing institutions but also its applicability to the well-known sluggishness of physical housing structures.

\section{Models of gradual institutional change}

In weak path dependence, the reinforcing mechanisms of path dependence suggested by Bengtsson and Ruonavaara (efficiency, legitimacy, and power) can in principle be turned upside down, because their disruption implies a moment of change. The disruption of the prevailing mechanisms of efficiency, legitimacy, and power can be considered the basic ingredients in the STM model and will be treated as such in the following text.

The STM model was developed in the study of the creeping liberalisation that most Western nations have been undergoing since the 1970s. In the absence of dramatic critical junctures, it was difficult to explain the considerable changes that had occurred by the 2000s using theories of path dependence, which would predict stable trajectories and change only through exogenous shocks. Thus, incremental change leading to discontinuity needed to be theorised anew, and the response to that need was the creation of a hands-on fivefold typology. The typology suggested by Streeck and Thelen is reproduced in Table 1. 
Table 1: Five types of gradual transformations

\begin{tabular}{|c|c|c|c|c|c|}
\hline & Displacement & Layering & Drift & Conversion & Exhaustion \\
\hline Definition & $\begin{array}{l}\text { Slowly rising salience } \\
\text { of subordinate } \\
\text { relative to dominant } \\
\text { institutions }\end{array}$ & $\begin{array}{l}\text { New elements attached } \\
\text { to existing institutions } \\
\text { gradually change their } \\
\text { status and structure }\end{array}$ & $\begin{array}{l}\text { Neglect of institutional } \\
\text { maintenance in spite of } \\
\text { external change resulting } \\
\text { in slippage in } \\
\text { institutional practice } \\
\text { on the ground }\end{array}$ & $\begin{array}{l}\text { Redeployment of old } \\
\text { institutions to new } \\
\text { purposes; new purposes } \\
\text { attached to old } \\
\text { structures }\end{array}$ & $\begin{array}{l}\text { Gradual breakdown } \\
\text { (withering away) of } \\
\text { institutions over time }\end{array}$ \\
\hline Mechanism & Defection & Differential growth & Deliberate neglect & $\begin{array}{l}\text { Redirection, } \\
\text { reinterpretation }\end{array}$ & Depletion \\
\hline Elaboration & $\begin{array}{l}\text { Institutional incoherence } \\
\text { opening space for } \\
\text { deviant behavior } \\
\text { Active cultivation of } \\
\text { a new 'logic' of action } \\
\text { inside an existing } \\
\text { institutional setting } \\
\text { Rediscovery and } \\
\text { activation of dormant } \\
\text { or latent institutional } \\
\text { resources } \\
\text { 'Invasion' and assimilation } \\
\text { of foreign practices }\end{array}$ & $\begin{array}{l}\text { Faster growth of new } \\
\text { institutions created on } \\
\text { the edges of old ones } \\
\text { New fringe eats into } \\
\text { old core } \\
\text { New institutional layer } \\
\text { siphons off support } \\
\text { for old layer } \\
\text { Presumed 'fix' } \\
\text { destabilizing } \\
\text { existing institutions } \\
\text { Compromise between } \\
\text { old and new slowly } \\
\text { turning into defeat } \\
\text { of the old }\end{array}$ & $\begin{array}{l}\text { Change in institutional } \\
\text { outcomes effected by } \\
\text { (strategically) neglecting } \\
\text { adaptation to changing } \\
\text { circumstances } \\
\text { Enactment of institution } \\
\text { changed, not by reform } \\
\text { of rules, but by rules } \\
\text { remaining unchanged in } \\
\text { the face of evolving } \\
\text { external conditions }\end{array}$ & $\begin{array}{l}\text { Gaps between rules and } \\
\text { enactment due to: } \\
\text { (1) Lack of foresight: } \\
\text { limits to (unintended } \\
\text { consequences of) } \\
\text { institutional design } \\
\text { (2) Intended ambiguity } \\
\text { of institutional rules: } \\
\text { institutions are } \\
\text { compromises } \\
\text { (3) Subversion: rules } \\
\text { reinterpreted from below } \\
\text { (4) Time: changing } \\
\text { contextual conditions } \\
\text { and coalitions open up } \\
\text { space for redeployment }\end{array}$ & $\begin{array}{l}\text { Self-consumption: } \\
\text { the normal working } \\
\text { of an institution } \\
\text { undermines its } \\
\text { external preconditions } \\
\text { Decreasing returns: } \\
\text { generalization changes } \\
\text { cost-benefit relations } \\
\text { Overextension: limits } \\
\text { to growth }\end{array}$ \\
\hline
\end{tabular}

Source: Reproduced from (Streeck and Thelen 2005: 31).

Mahoney and Thelen (2009) take the model one step further by relating the different sources of institutional change to each other in a systematic way. Accordingly, displacement means the removal of old rules and the introduction of new rules. In the cases of layering, drift, and conversion, the old rules are not formally removed. In layering, new rules are attached to the old ones. With drift, the old rules are kept but neglected and their impact and enactment are changed, and with conversion, the old rules are also formally kept but are interpreted and enacted in new ways. Streeck and Thelen's fifth type, exhaustion, is not included in Mahoney and Thelen's development of the model, but it can be defined as situations where existing rules are removed (and neglected) without any new rules being introduced.

Notably, the authors only discuss change in formal institutions. Owing to the particular nature of housing, we also include the physical and social structures that housing is made of and embedded in. Further, since the stabilising function of formal rules largely depends on shared social norms and practices - for example, via the legitimacy mechanism - we also include such social institutions in our definition. Thus, our analysis is based on a broad understanding of 'housing regime', adding 'physical organisation' to Kemeny's definition of 'housing regime' as 'the social, political and economic organisation of the provision, allocation and consumption of housing' (Kemeny 1981: 13). 


\section{Incremental change in housing: structures and institutions}

Much more than other welfare domains, housing is tied to the material infrastructure and the social structure of residents. Changes in the underlying social and physical structures often, but not always, accompany institutional change.

\section{Change in physical housing structures}

The five metaphorical terms that describe gradual change in the STM model can be used as almost literal descriptions of physical changes in housing structures. Change through layering is the most obvious example: housing is literally structured in vertical layers of multiple stories or horizontal layers with tree-ring-like patterns encircling a city's core. When European cities were still fortified they often grew vertically, while since then horizontal layering has been more important. The inertia of vested interests and of building traditions can impede the process of change in existing stock. The addition of new layers, in turn, allows for an element of change that leaves the existent stock virtually untouched. For example, without renovation of the existing stock, it will take generations to make the entire housing stock energy-efficient. The 'layering' of new owner-occupied single-family suburbs in Germanspeaking countries increased the homeownership rate during the $20^{\text {th }}$ century, while the core of multi-unit rentals that were surrounded by new suburb layers still kept the overall homeownership rate at its internationally low level (Kohl 2016). Eventually, however, the accumulation of many suburban layers will also affect the city's core in terms of declining population shares, selective migration, and loss of tax revenue and political power. Thus, the story of change over time is told by what share each form of housing makes up in each layer of new construction and demolition.

Change through conversion can also acquire a physical meaning in the case of housing, as when material changes are undertaken in order to rededicate the use of existing housing structures. The conversion of existing military buildings or commercial areas for residential use and the conversion of large apartments into separate housing units after the Russian Revolution are obvious examples. Rapid material conversions of this kind may be found in times of housing shortage or technological change.

One determining feature of change in housing is decay. Housing structures, through their physical make-up, deteriorate over time. The longevity of a particular form of housing is determined by the projected life of a building or buildings. With relatively short programmed lifecycles of 20-30 years, for instance, the end of many social housing projects was basically written in stone (or rather a cheaper building material). Even though housing has low depreciation rates compared to other investment goods, it still becomes obsolete after a certain number of years. This basic condition of housing structures can be described as gradual change through exhaustion.

The obsolescence of housing structures can even be exacerbated through deliberate neglect, which is at the core of the gradual mode of change called drift. One example of drift is when maintenance is neglected in the existing housing stock so that it can be replaced. Slum landlords, for instance, deliberately overcrowd old housing structures and drive out existing residents in order to be able to tear down structures, sell the land for construction, and build anew (Desmond 2016). 
Finally, the displacement of housing structures requires the co-existence of various forms of housing at a certain point, some possibly dominant, others dormant. A minor housing alternative can then be rediscovered and reactivated, endogenously or through the import of foreign ideas. The renovation of existing units at the onset of the gentrification process is an example of displacement, as is the more radical urban redevelopment of entire districts. With depreciation built into existing housing, the complete displacement of older buildings and neighbourhoods is a permanent dormant alternative to existing housing, particularly when land values largely outpace the value of existing structures.

The modes of gradual change are thus already quite literally carved into the very material structures that houses are made of, and, in principle, independently of how housing is institutionally organised. De facto, of course, the material and institutional spheres of housing are often closely enmeshed and only analytically separable. This will also become evident in the following examples of gradual institutional change.

\section{Change in housing institutions}

The logic of layering in housing institutions is similar to that observed in other welfare areas (e.g. pensions and schooling): the initially capital-heavy public programmes were outgrown by their own dynamics or demography and parallel layers of incentive programmes for more private provision systems began to grow faster (Rothstein 1998). In housing, indirect subsidies through fiscal exemptions directed at homeowners, which are layered on top of the declining direct subsidies favouring social rental constructions, are a case in point. Often introduced as incentive programmes for more construction in times of building scarcity, in most countries they became a major subsidy line that outstripped the direct subsidies for social rental housing.

If we accept the STM definition of conversion - i.e. the old rules are formally retained but are interpreted and enacted in new ways - institutional conversion in housing is often social rather than formal. For example, extensive changes in tenure structure (typically due to institutional change), like the right to buy in Britain, may eventually also lead to social redefinitions and new shared understandings of tenures like homeownership and public housing. Thus, both formally and socially, the conversion of public housing into owneroccupation is one of the central instances of institutional conversion in housing.

One example of endogenous displacement through the activation of inside actors is the institution of apartment ownership in Germany (Kohl 2017). The Civil Code of 1900 outlawed this old legal institution because apartment ownership was seen both as a breach of the notion of undivided, absolute property and as a cause for permanent dispute. When, after World War II, capital for reconstruction was urgently needed, conservatives re-activated the older legal tradition in order to mobilise more capital and to spread more homeownership in the unstable post-war period. But unlike Southern European countries where this property form became important, legal issues and the concern of banks about using apartments as collateral had the effect of marginalising apartment ownership in the German housing stock until the 1970s. Then a second re-activation attempt, this time initiated by the Social Democrats, showed more success. Home acquisition subsidies were extended to include existing houses and apartments and a procedure for the conversion of private rentals into 
separately owned apartments was designed. As the trend of single-family-home suburbanisation abated, apartment ownership became a new housing form in many German cities, and political actors shifted attention from private rentals to apartment ownership. A latent institution has since become re-activated.

Drift in housing institutions refers to change through economic or administrative neglect, parallel to the lack of attention to and maintenance of housing structures discussed above. One key example is the gradual hollowing out of public housing institutions in many countries. For example, the cost ceilings on maintenance costs, which Republicans added to the New Deal's Wagner Housing Act of 1937, were the death knell of American public housing, whose buildings often did not attain the planned life expectancy. Drift can often be caused by political neglect in the form of non-decisions, and, even without formal change, social housing estates in many countries have succumbed to the disease of rising costs owing to social problems that increase maintenance costs.

Finally, exhaustion refers to institutions that are programmed to solve certain problems, after which they become obsolete. In many countries, housing institutions were set up to deal with post-war or recession-related indebtedness problems, and ministries of construction were often formed as ministries of 'reconstruction' and then faded away once reconstruction was achieved. The American Home Loan Corporation and Hypo Real Estate in Germany were founded to consolidate and settle problematic mortgages, and then dissolved as a result of their success dynamics. Another type of exhaustion occurs when an institution dissolves because of its own dynamics of failure. The socialist housing supply model, for instance, was based on artificially low rent levels and a simultaneously declining tax contribution for maintenance. As a result, the housing capital stock was largely depreciated by 1990 .

\section{Discussion and conclusion}

Generally, one advantage of the STM model, when applied to housing, is that its guiding metaphors can be used to describe the solid material structures that houses and buildings are. Our analysis even indicates, paradoxically, that the model may be easier to operationalise on the physical structures of housing than on its institutions. When applied to housing institutions, metaphorical and loosely defined descriptions come at the price of precision. Our analysis illustrates what has been noted in one previous reference to STM in housing matters (Kemp 2015), namely, that it is at times difficult to decide exactly which of the modes of change and which of the mechanisms are at work - or whether more than one of them are present together. It is especially difficult to draw the line between drift, layering, and conversion, where incremental change occurs even though the old institutions have not been formally removed. Furthermore, what in the short run is layering or drift may in the long run result in exhaustion. Different and parallel modes of change may also complicate the analysis. Finally, which mechanism best describes a certain development may sometimes depend on how institutions are defined and demarcated. For example, since an integrated rental market includes both the private and public rental sector, layering or drift within one of these sectors may at another level be defined as the conversion of the integrated rental sector as a whole.

Some of the changes we discussed above might be better captured by more traditional pathdependence approaches - for example, the disruption of the East German housing regime and the British 'Right to Buy' reform. However, even such changes are often preceded and 
followed by processes of long-term incremental change. Consequently, a fruitful approach to understanding long-term change may often be to combine path dependence and STM models in the analysis: radical and incremental change can overlap, such as in cycle theories with longer and shorter cycles, they can push in different or similar directions of change, or one may be followed by the other. Critical junctures may also trigger processes of more incremental further change - not necessarily just path-dependent processes - and these could culminate in more radical changes. Finally, a radical change in one domain of housing can be accompanied by more incremental ones in another segment.

Another observation is that the intermeshed processes of structural change and institutional change are particularly applicable to housing. As illustrated in our examples, housing structures are often closely tied to specific institutions: the private rental stock is tied to the institutions of rental tenancy and to landlord and tenant organisations; the public and social housing stock is tied to municipal or social housing companies and to laws regulating social tenancy and subsidies, etc. In many countries, exhaustion in social housing implied both a decline of the social housing stock and social housing institutions.

As mentioned, the STM framework has been applied mainly to policy areas other than housing and situated in the more classical welfare domains - for example, the often-studied areas of pensions, education, or health. Although the rigidity of demographic generations affects virtually all policy fields, the particularity of housing first lies in the long-term material structures that it generates. In that, gradual change in housing may resemble more the long-term investment cycles of infrastructural policies than the generation cycles of welfare policies or the business cycles of economic or industrial policy.

A second characteristic that sets housing apart from other policy fields is its strong reliance on market provision, even in non-liberal welfare states. For the analysis of gradual change, this could imply that housing institutions, despite the stickiness of housing structures, can change more rapidly from state to market - and possibly back - than might be conceivable in other policy fields. This paper was meant to fill the gap left by path-dependence approaches in the study of gradual change phenomena in the field of housing. Our main conclusion theoretical and methodological - is that long-term change in national housing regimes is probably most fruitfully analysed as a reciprocal interaction between physical and social structures, between formal and social institutions, and between critical junctures and incremental change. In this kind of dynamic analysis, the STM model should have an important role to play. 


\section{References}

Bengtsson, B., H. Ruonavaara 2010. "Introduction to the Special Issue: Path Dependence in Housing.” Housing, Theory \& Society 27 (3): 193-203. DOI: 10.1080/14036090903326411.

Crouch, C., H. Farrell 2004. "Breaking the path of institutional development? Alternatives to the new determinism.” Rationality and Society 16 (1): 5-43. DOI:

$10.1177 / 1043463104039874$.

Desmond, M. 2016. Evicted. Poverty and Profit in the American City. Milwaukee: Crown Publishers.

Kährik, A. 2006. Socio-spatial residential segregation in post-socialist cities: the case of Tallinn, Estonia. Dissertation, University of Tartu.

Kemeny, J. 1981. The Myth of Home Ownership. Private Versus Public Choices in Housing Tenure. London: Routledge.

Kemp, A. P. 2015. "Private Renting After the Global Financial Crisis.” Housing Studies 30 (4): 601-620. DOI: 10.1080/02673037.2015.1027671.

Kohl, S. 2016. "Urban History Matters: Explaining the German-American Homeownership Gap.” Housing Studies 31 (6): 694-713. DOI: 10.1080/02673037.2015.1121213.

Kohl, S. 2017. Homeownership, Renting and Society: Historical and Comparative Perspectives. London: Routledge.

Mahoney, J. 2000. "Path Dependence in Historical Sociology.” Theory and Society 29 (4): 507-548. DOI: 10.1023/A:1007113830879.

Mahoney, J., K. Thelen 2009. “A Theory of Gradual Institutional Change.” Pp. 1-37 in J. Mahoney, K. Thelen (eds.) Explaining Institutional Change: Ambiguity, Agency, and Power. Cambridge: Cambridge University Press.

Malpass, P. 2011. "Path Dependence and the Measurement of Change in Housing Policy." Housing, Theory \& Society 28 (4): 305-319. DOI: 10.1080/14036096.2011.554852.

Nielsen, G. B. 2010. “Is Breaking Up Still Hard to Do? - Policy Retrenchment and Housing Policy Change in a Path Dependent Context.” Housing Theory and Society, Theory and Society 27 (3): 241-257. DOI: 10.1080/14036090903326486.

Rothstein, B. 1998. Just Institutions Matter: The Moral and Political Logic of the Universal Welfare State. Cambridge: Cambridge University Press.

Sorensen, A. 2015. "Taking path dependence seriously: an historical institutionalist research agenda in planning history.” Planning Perspectives 30 (1): 17-38. DOI:

10.1080/02665433.2013.874299. 
Streeck, W., K. Thelen 2005. “Introduction: Institutional Change in Advanced Political Economies.” Pp. 1-39 in W. Streeck, K. Thelen (eds.) Beyond Continuity: Institutional Change in Advance Political Economies. Oxford and New York: Oxford University Press. 